Media Industries 8.1 (2021)

\title{
Structured Industry Workshops as Methodology: Researching National Screen Agencies and Policies ${ }^{1}$
}

\author{
Eva Novrup Redvall ${ }^{2}$ \\ UNIVERSITY OF COPENHAGEN \\ eva $[\mathrm{AT}]$ hum.ku.dk \\ Inge Ejbye Sørensen ${ }^{3}$ \\ UNIVERSITY OF GLASGOW \\ inge.sorensen [AT] glasgow.ac.uk
}

\begin{abstract}
This article explores the advantages of "structured industry workshops" as a methodology for obtaining nuanced empirical data about the practices and "behind-the-scenes" workings of national screen agencies, organizations, institutions, and stakeholders. The article argues that structured industry workshops with industry informants in the media industries have five major methodological benefits. The workshops facilitate access to and interest from elite or expert informants who can otherwise be hard to attract; they counter the risk of spin and "corporate scripts"; they provide a valuable forum for not only finding out what practitioners think, but also how they discuss and engage with other practitioners; they generate new lines of academic inquiry and run counter to current thinking, policies, or dogma; and finally, structured industry workshops can help establish a platform for sustained dialogue and industryacademy collaborations, with genuine knowledge exchange and coproduction as well as potential for impact.
\end{abstract}

Keywords: Exclusive/Industry Informants, Workshops as Methodology, Media Industries, Production Studies, Industry-Academy Collaborations 


\section{Introduction}

Conducting media industry analysis of the work and practices of film funders, agencies, and television commissioners requires access to media elites or "exclusive informants" ${ }^{4}$ who are willing to talk to scholars about their work. The most common strategy for achieving this is to conduct qualitative, semi-structured interviews where funders and commissioners share their experiences and perspectives. As analyzed by many media industry scholars, this process is often affected by problems of access to busy industry professionals and of challenges related to a lack of time-for the informants as well as researchers. ${ }^{5}$ Moreover, interviews with these exclusive informants are often marked by a knowledge and status asymmetry between interviewees and interviewer ${ }^{6}$ and the risk of the interviews effectively being what John T. Caldwell calls "corporate scripts" where practitioners "sell" their desired version of why and how things are and should be done. ${ }^{7}$

Based on three international research workshops in the project Commissioning Creativity and Funding Film in Glasgow and Copenhagen 2016-2017, ${ }^{8}$ this article argues that another productive, as well as time- and cost-effective, research strategy for obtaining empirical data about the "behind-the-scenes" workings of different national screen agencies and funding organizations, as well as policy and commissioning frameworks, is to bring together targeted, expert informants in themed and structured industry workshops. We call this methodology "structured industry workshops."

Drawing on the structure and findings from the Commissioning Creativity and Funding Film workshops, and on academic literature on research methods in relation to studying the media industries, this article outlines five benefits of organizing such workshops. Structured industry workshops present an effective way to generate nuanced data about what Matthew Freeman calls "the operational thinking and belief systems" of the media industries, when trying to, in Des Freedman's words, "go beyond the often procedural and technical accounts of media policy to offer a broader picture of the voices, arguments, actors, arenas, and controversies that dominate contemporary media policy-making." ${ }^{\circ}$ The five benefits of the structured industry workshops are that they can be (1) a means to gain attention and access, (2) a way to move beyond "corporate scripts," (3) a setting where one can observe how practitioners engage and exchange knowledge, (4) a pathway to potential industry and policy impact and change as well as future academic inquiry, and, finally, (5) an opportunity to facilitate sustained dialogue between industry and academy.

Outlining these benefits in more detail, the article also discusses how the structured industry workshop is most effectively conducted and the differing contexts where it can be successfully employed. In the case study that forms the empirical basis for this article, the workshops were conducted with practitioners who work in small-nation, state-subsidized institutions and agencies in Northern Europe and who were curious about the practices and procedures in similar settings. However, we conclude the article by arguing that the methodology can also be effectively applied to other groups or constellations of screen industry workers with comparable professional profiles, institutional backgrounds, or organizational affiliations in different national settings and industry frameworks. 


\section{Studying Work Practices and Belief Systems in the Media Industries}

As discussed in the extensive literature on quantitative and qualitative social and media research methods, ${ }^{11}$ there are many challenges when researchers want to study the real-life operations of particular institutions or the work and beliefs of practitioners. What Alan Bryman describes as the "the messiness"12 of social research can be challenging for students and scholars alike, not the least when studying the media industries where informants often work as freelancers or on limited-term contracts, and wish to present themselves as success stories in order to secure the next job.

Academic media literature is awash with accounts of the challenges of getting access and navigating complex power structures when, for instance, interviewing industry executives or A-list talent. ${ }^{13}$ When dealing with what Hanne Bruun calls "exclusive informants"14 whose knowledge is crucial for being able to conduct a particular research project, how to negotiate access and the terms for gaining this access is always an issue. One is trying to set up meetings with busy people who quite rightly might wonder "what's in it for me?" and for whom giving interviews with academics is not a priority. ${ }^{15}$

In production studies, scholars such as Caldwell vividly describe the need to continuously stay critical of widespread "corporate scripts." In Matthew Freeman's book on industrial approaches to media, intended as a "methodological gateway" to industry studies, numerous scholars note a number of "frictions and frustrations" that often characterize exchanges between the industry and the academy. ${ }^{17}$ These frictions and frustrations when targeting people at the top of the food chain have led some scholars to deliberately "study down" rather than up. As discussed by Vicki Mayer in her article "Studying up and F***ing up" on ethnographic interviewing in production studies, the challenges related to focusing on above-the-line talent can be exhausting, and there can be great intrinsic value in "studying down," as Mayer demonstrates in her research on below-the-line workers in the global television industries. ${ }^{18}$ The anthropologist Sherry Ortner advocates strategies of studying "sideways" by evoking the shared social circles, networks, frames of reference, educational backgrounds, and cultural capital of creative workers, academics, and policymakers, who all occupy the "knowledge classes." 19 Drawing on personal connections and professional networks for access to "closely guarded communities" and additional "insider" insights is therefore a widely used and effective methodological strategy for practitioners-turned-academics, who occupy positions of "both sides of the fence." 20

However, if one's interest is to study the work of national screen agencies, one has to engage with commissioners and funders in order to generate the empirical data needed to undertake the analysis. Qualitative interviews with exclusive informants are common in this regard, and there are several useful publications on how to conduct this kind of research, across various disciplines more generally ${ }^{21}$ as well as in the media industries ${ }^{22}$ and specifically within screen agencies in the United Kingdom and Scandinavia. ${ }^{23}$

Much can be learned from this way of engaging with individuals in the media industries, not the least if combined with ethnographic or observational methods which have, as noted by 
Christian Herzog and Christopher Ali, often been "relegated to a niche existence in both media and communications policy studies." 24 Observations can take different forms of what Barbara Czarniawska calls "shadowing" when writing about techniques to do fieldwork in modern societies ${ }^{25}$ or take place in relation to practitioners' everyday work (see, for example, the seminal work of Georgina Born and Philip Schlesinger ${ }^{26}$ ). There is also great value in observing industry events as well as the artifacts or "deep texts" in or about an industry, ${ }^{27}$ as, for example, carried out by Timothy Havens when studying the work and business practices in the global television marketplace. ${ }^{28}$ Triangulating data and mixing methods are useful and often necessary, ${ }^{29}$ particularly when analyzing production cultures, media industries, and systems that are, in the words of Caldwell, "far too messy, vast and contested to provide a unified code." ${ }^{30}$

\section{Industry Workshops as Methodology}

Both authors have previously worked extensively with qualitative methods and, in particular, elite interviews and observation when researching the production of Danish film and television drama or the British screen industry and international documentary production. ${ }^{31}$ In our attempt to obtain valid data about the current practices for commissioning and funding films across a number of Northern European countries, we decided to organize a series of workshops with exclusive industry informants with valuable and privileged knowledge about our research topic. The ambition for these themed and structured industry workshops was to place our research questions on the agenda and not only acquire answers from each individual but also observe how industry practitioners engaged and shared their knowledge and opinions with each other. Moreover, we hoped that this would facilitate and generate open discussions about current practices and policies as well as ideas about the future of commissioning and funding films, which is often a key interest in production studies and policy research. $^{32}$

Other scholars have worked with similar research designs. In Europe, for instance, Lisa W. Kelly and Katherine Champion organized knowledge exchange workshops (funded by the Royal Society of Edinburgh) designed to initiate dialogue between academics, policymakers, and stakeholders about different conceptualizations and understandings of the notion of screen talent. ${ }^{33}$ Naomi Sakr and Jeanette Steemers have conducted several industry workshops as part of their research project on Children's Screen Content in an Era of Forced Migration. ${ }^{34}$ In the United States, the Transforming Hollywood summits, ${ }^{35}$ arranged by Denise Mann and Henry Jenkins with the industry, have staged similar events, and The Connected Viewing Initiative, a collaborative venture between scholars and Warner Bros. Home Entertainment organized by the Carsey-Wolf Center's Media Industries Project at University of California, Santa Barbara, was to some degree also built around this methodology. ${ }^{36}$

Working with structured industry workshops entails many of the common challenges of media industry research. There are clearly differences between organizing these kinds of workshops in differing production cultures, and there is always a risk that the workshop 
setting is used by academics and industry informants to stage performances of status, power, and expertise. However, we do find that this method has the potential to generate new kinds of knowledge and create productive communities of critical practice that makes constructively dealing with these challenges worthwhile.

In the following, we will discuss the five methodological benefits (rather than our findings) of organizing structured industry workshops.

\section{The Commissioning Creativity and Funding Film Workshops}

The international workshop series Commissioning Creativity and Funding Film ${ }^{37}$ brought together academics and key representatives of national public screen agencies from Denmark, Norway, Sweden, the Netherlands, and Scotland to discuss the common challenges that face screen agencies in smaller Nordic and Northern European screen economies. In order to explore how national screen agencies implement and enact policy in practice, the workshops compared and contrasted the practices, policies, structures, and initiatives of screen agencies in nations with similar levels of wealth; analogous political systems; sociodemographic composition; and comparable educational and cultural standing, activity, and aspirations.

Each workshop was structured as open dialogue and discussions of themed research topics in a symposia with between eleven and thirteen expert informants from screen agencies as well as academics. ${ }^{38}$ Workshop 1 explored external pressures from national and international policies as well as global media players on national screen commissioners' funding frameworks and practices. Workshop 2 focused on internal and institutional structures and the role and everyday work of the funder/commissioner. Workshop 3 interrogated collaborations and coproduction in Northern Europe with emphasis on how funders and agencies seek to nurture and sustain screen industries and facilitate the most creative productions. We moderated the workshops and asked questions to enable discussion. In order to highlight the research theme and direct the discussion, the workshops were introduced by short scholarly presentations and concluded with analytical reflections summarizing the key points and findings. This dialectics between knowledge exchange and reflections facilitated a coproduction of knowledge between academics and industry participants.

The findings from these workshops were then presented for discussion to screen industry representatives at a roundtable discussion at Glasgow Film Festival's Industry Focus in February 2017. The purpose of this concluding event was threefold: first, to share the findings and discussion with the local production industry and community, some of whom were especially invited (e.g., representatives from BBC Scotland and the local producers' association Independent Producers Scotland), in a festival forum as well as in a more informal setting during a reception afterward; second, to put the findings to the test and wider scrutiny in front of the production community, and in this way strengthen their validity; third, to facilitate genuine dialogue between screen agencies, industry, and academics. 


\title{
The Five Benefits of Structured Industry Workshops
}

\author{
Structured Industry Workshops as a Means to Gain Attention and Access
}

Gaining the attention of busy industry people and access to their time is always a challenge in production studies. ${ }^{39}$ Structured industry workshops are a way to signal the importance of the research and create a setting where media professionals not only provide information to academics, but also exchange knowledge and experiences with national and/or international colleagues. In qualitative interviews, snowballing is a well-known strategy for asking one interviewee to facilitate the connection to the next. ${ }^{40}$ The question is, of course, where you find the first snow for the ball, or persuade the first person to sign up, and how to make participation attractive to this person's peers. Workshops can be a more attractive proposition than traditional interviews because, rather than simply allocating time to discuss one's own work for the sake of academic research, there are also opportunities to network.

Also, the findings from the structured industry workshops can complement institutional and organizational requirements and research agendas. In our experience, those working for and within publicly funded film agencies or at public-service television broadcasters are likely to be contractually obliged to dedicate time to knowledge sharing, because these organizations are funded from the public purse and have requirements for transparency and accountability. This makes conducting structured industry workshops more viable in some production cultures rather than others. However, the workshop methodology is also effective with industry professionals in the commercial sector where there is no direct requirement or obligations for engagement, as well as in screen industries in countries without publicservice media traditions (we will discuss this below). This is because stakeholders in the media industries tend to be effective networkers and see this as part of their professional work. They meet regularly at industry events, the festival circuit, or at screen commissioning and funding events and markets. There is an understanding within the screen industry that meeting in these ways is worthwhile. Structured industry workshops replicate this by organizing a similar setting and event, but with a particular research focus rather than an industry agenda.

\section{Structured Industry Workshops as a Way to Move beyond "Corporate Scripts"}

Most media professionals are used to speaking in public and being heard, and it can be quite a task as researcher to retain control of the discussion and make sure that the topics on the workshop agenda remain in focus. Structured industry workshops create a setting where generating data is less marked by what Jennifer Holt notes are "the hazards associated with the industry interview" and "the need to sift through 'spin' and promotion.."11 Being in a room with professional colleagues makes it harder to present glossed-over, glorified, or embellished accounts that are not based on the actual realities of the work carried out, as, for example, the research of Caldwell ${ }^{42}$ or Alison Preston ${ }^{43}$ illustrate can otherwise be the case. 
In Caldwell's words, it is harder to bullshit when there are other people in the room who know the workings of a particular industry, and more difficult to get away with easy answers. When one wants to learn more about an "industry's own self-representation, self-critique, and self-reflexion," ${ }^{\prime 4}$ structured industry workshops are thus a valuable method. The screen professionals in the room-who tend to focus more on their peers rather than the researcherswill engage in lively discussions and are eager to pick each other's brains, as well as sharing knowledge about different matters.

In our workshops, there would occasionally be references to the official and the less official versions of events and issues, and comments that could not leave the room. Therefore, it is important to have a solid sense of trust in the room, ${ }^{45}$ for example, through Chatham House rules, as well as clear agreements that people can talk off the record without fear of this being published in an academic article later. Even if things are said off the record, it allows researchers to gain a better understanding of an industry and ask sharper and more critical questions in the specific project as well as in future research. A structured industry workshop should be a space where ideas and experiences can be shared, but also commented on in confidence.

Patrick Vonderau notes that there can often be a sense of mistrust when "unlike cultures" such as "theory" and "practice" meet, and that negotiating these "trading zones" 46 and creating a sense of trust are paramount. This is particularly important if one wants to learn not only about the usual stories of successful best practice, but also about issues that are challenging and might even relate to less successful projects. Most film agencies, broadcasters, policymakers, and other people and institutions in the film and media industries are always under pressure to present themselves as successful to win legitimacy and funding. However, much can be learned from sharing experiences of where things went wrong or where one took a risk on something that did not turn out as expected. There is a lack of this kind of knowledge sharing in the industry, and no immediate desire or incentive to discuss this with researchers. Structured industry workshops can present a setting where one can talk about success as well as failure, about initiatives that did not work out, or about ideas that one might be skeptical of implementing, and use the experiences of others as a sounding board. Our workshops provided several examples of participants discussing why they had decided not to pursue something or sharing in-house experiences that we would probably never have learned about had they not been keen to hear the experiences, perspectives, and opinions of their peers. As researchers, we gained valuable knowledge through the workshop setting that we most likely would not have obtained in ordinary one-to-one interviews.

Structured Industry Workshops as Observation of How Practitioners Engage and Exchange Knowledge

In the workshops, we had gathered what Uwe Flick, writing about focus groups, calls a "real group (which is confronted in its everyday life by the research issue)." ${ }^{\prime 4}$ Flick describes how participants in such groups "are likely to express more and go further in their statements than in single interviews. The dynamics of the group become an essential part of the data and their collection." 48 The workshops did not only provide the opportunity to gain knowledge about what industry professionals think about certain matters but also to observe how practitioners discuss these matters. They provided an ideal forum for exploring what can be 
regarded as industry interaction when practitioners discuss their work and practices among themselves.

Although focus groups as a method allows for substantial moderation, this method falls short of the level of interaction and interdisciplinary dialogue that can be facilitated and achieved within the structured industry workshop format. Part of our workshop ethos was that the academics and practitioners participated in the discussion as equals. This dialogue and ongoing critical analysis disrupted and challenged what Timothy Havens discusses as "industry lore" ${ }^{49}$ or established common sense understandings among practitioners. This created a continual feedback loop, synergy, and ongoing analysis, which allowed for a more rigorous interrogation of how practices and policies were implemented within the screen agencies.

Issues of culture, power, status, and gender are always an important consideration when conducting this kind of research. Steemers observes that gathering industry professionals in a room can reveal remarkably different ways of doing things, as well as ways of talking about one's work and engaging with that of others. Steemers found that the Nordic participants in the international workshops related to her Arab-European research did not mind being criticized, while other nationalities often found being questioned challenging. Her workshops also illustrated how there can be problematic power plays in a room between more senior and junior professionals. ${ }^{50}$ In our workshops, the conversations appeared to be quite open and frank. We believe that this is partly because the exclusive informants in the room regularly engage in similar kinds of industry discussions and come from smaller, state-supported production cultures where one is expected to share, compare, and discuss strategies. The cultural proximity between participants and their work settings further enforced this, as did the shared production agendas of Northern European commissioners and funders. In addition, we endeavored to level the "power proximity" between the participants by ensuring that the workshops were gender-balanced and by inviting participants who occupied similar roles.

This structure and organization of the workshops, as well as the concluding industry event, created a forum of "dialogic" voices, to borrow freely from Mikhail Bahktin. ${ }^{51}$ The effect of this nonhierarchical knowledge exchange among the stakeholders who contributed to the discussion as equals created a sense of mutuality that allowed for a productive knowledge exchange between industry, stakeholders, and academics.

Structured Industry Workshops as Pathways to Industry

and Policy Change as well as Future Academic Inquiry

The focus of the workshops was to explore the interaction and interdependence between organizations, stakeholders, practitioners, policies, and practices across multiple levels simultaneously. The dialogic element of the structured industry workshops facilitated this, and this approach also proved productive for exploring the complexities and synergies between policy and practice as well as between individual agents and their organizations.

Amanda Lotz and Horace Newcomb's seminal article "The Production of Entertainment Media" theorizes the methodological implications of the particularities of media industry studies. Lotz and Newcomb align specific, dominant sources and relevant methods to different "levels of analysis" in production research: from studies of international and national 
political economies, over industrial and organizational contexts, to explorations of audience, and the practices of agents, producers, and prosumers. In the article, they stress the interdependence and synergy between these different levels of analysis and note the mixedmethods approach this necessitates. ${ }^{52}$

The structured industry workshop format was advantageous for exploring the intertwined complexities between these levels. The discussions at the workshops offered historic, socioeconomic, and cultural perspectives on and comparisons of how processes, practices, and priorities have evolved in screen agencies across the different national settings and policy frameworks. It also uncovered what screen practitioners and agencies saw as the potential and challenges for the screen industries in the years ahead.

The ambition of the workshops was not to have a direct impact on policy, but rather to create a setting where it was possible to both curiously and critically question traditional approaches to commissioning and funding films, as well as explore new ideas and initiatives. That said, the sharing of new thoughts and plans between screen agencies has the potential to influence future policy directions. For example, after the workshops, Screen Scotland adopted more transparent criteria for screen funding, and the Danish Film Institute reassessed its policies for diversity and equality, ${ }^{53}$ but it is of course impossible and maybe naïve to attribute these initiatives directly to the workshops.

For the academics, the workshops offered new ideas and avenues of research, for instance, on the topic of gender and diversity that was often debated in the workshops and proved to be surprisingly differently understood and negotiated in different national contexts. Similarly, the unintended consequences of certain funding forms, especially automatic funding, were much more controversial than anticipated ${ }^{54}$ While we as researchers had a certain agenda ahead of the workshops, this agenda and scope of the workshops evolved once the practitioners started talking among each other about what they regard as the main current and future challenges. This provided us with insights and perspectives that we would not have encountered through semi-structured, individual interviews.

Structured Industry Workshops as a Means to Facilitate

Sustained Dialogue between Industry and Academy

For many years, scholars have recommended increased interaction and engagement between industry and academics. In her 2013 article "Two-Way Mirrors: Looking at the Future of Academic-Industry Engagement," Jennifer Holt outlined a range of new, interactive, and collaborative methodologies that combine the need for dialogue, observation of practices, and interaction between academics and media practitioners. ${ }^{55}$ John Ellis has emphasized the value of establishing "sustained dialogue" between academic researchers and the industry over longer periods of time. ${ }^{56}$ The final roundtable of the inaugural Media Industries Conference in London in 2017 centered on the relevance of scholars for the media industries and how this could be developed and enhanced.

This dialogue and sustained engagement take trust and a sense that there is value in engaging in a continuous conversation and allocating time to do this. Spending a day together at a structured industry workshop is a solid basis for establishing a relationship on which to build 
further research. In the short term, there are several obvious reasons for getting back in touch, such as fact-checking, publishing, or arranging dissemination at roundtable or panel discussions following the workshop. In the long term, it is natural to follow up on issues discussed during the workshop day, not the least inquiries about where an industry is heading.

Related to this, one should not underestimate the relation-building that comes from professional as well as personal conversations when having a shared meal or participating in a networking event in relation to a workshop. While there are inherent risks in this kind of relation-building and sustained dialogue-such as the potential loss of impartiality and integrity as discussed by Anna Potter ${ }^{57}$-there are also benefits if one avoids what Janice Radway has called falling into the trap of "self-indulgent narcissism" by wanting to reify one's own social position. ${ }^{58}$ We acknowledge that having spent time, energy, and funds organizing such workshops, we can be regarded as having a vested interest in assessing their methodological functionality in a positive light. This is a potential hazard of a "method article." We have tried to remain self-critical based on a conviction that there is value in scrutinizing and sharing methodological reflections and encouraging broader conversations about specific and new approaches in media industry studies. Conducting and writing about structured industry workshops are a way to create a framework for exchanges and dialogue where the benefits, in our opinion, outweigh these risks.

\section{Working with Structured Industry Workshops in Different National Settings and Sectors}

As illustrated in the above, we have found structured industry workshops to be a productive way of collecting data and engaging with exclusive informants in a Northern European research context. We acknowledge that this research strategy might be easier to pursue in small nation settings marked by cultural proximity and with comparable state-subsidized institutions and agencies. This creates a common reference frame as well as a sense of common interests across national policy and funding frameworks. The peer setting can help generate trust and has the potential to facilitate a genuine exchange of information, experiences, and expertise about practices, initiatives, and industries in different nations or regions.

In terms of the type and range of research questions that can be put on the agenda, we believe that structured industry workshops can target many different sectors and levels of the screen industries where access is often less restricted for scholars. As illustrated by the workshops organized by scholars in other production cultures, practitioners and industry informants will engage if the research topics are also pressing issues in the industry. We used the workshops to "study up," but they can be conducted within many different professions (e.g., directors, screenwriters, composers, or heads of technical departments) or institutions (broadcasters, regulators, videos on demand [VODs], etc.) and across sectors 
(film, TV, radio and podcasting, advertising, theater, publishing, screen-based media and music, etc.). As long as there are synergies and common reference points for the informants and the discussions are thematically structured, this methodology can work in a similar manner to the way that we conducted our research with heads of screen agencies and commissioners.

Similar to all other methodologies for researching the media industries, there are challenges related to gathering industry professionals in a room and keeping a clear focus on the research agenda. We valued being two researchers who organized the workshops and facilitated the discussions, and we regard the workshop as a natural place for joint ventures between researchers in the same or different institutions and disciplines. Working with colleagues in this way is also conducive for having the ongoing methodological debates that are needed, when the intention of a research project is to explore the specific workings of a particular part of the media industries and the tensions between practitioners' intentions and institutional practices.

To summarize, structured industry workshop can focus on many different settings and a variety of research questions. Crucial for the composition of the group is that there is synergy, cohesion, and clear advantages for reflexive exchanges of knowledge and experiences between academia and industry. It is this synthesis within the group that sparks and facilitates a coproduction of knowledge.

\section{Conclusion: Toward New Methods and Methodologies for Media Industry Studies}

As the study of the media industries matures as a research area, there is a need for developing new qualitative and quantitative methods and methodologies that can capture and reflect the complexities and nuances of ever-evolving production and distribution regimes in global and interconnected media industries, the arrival of new technologies, as well as the particularities of national screen economies. ${ }^{59}$ Paterson et al. note that, "multiple international research sites and comparative research designs . . . are still a rare occurrence." ${ }^{60}$ Structured industry workshops provide an effective method for comparing ideas of best practice and strategies internationally. Also, this approach negotiates some of the methodological shortcomings of other methods that are widely used in media and production research.

Structured industry workshops offer dialogue, knowledge exchange, and coproduction between academics and industry practitioners. This can impact policy and practices in the screen industries, as well as generate new and original lines of academic research. We know from the participants' feedback that the workshops have helped inform the thinking, working practices, and strategies within the screen agencies. For the researchers, the workshops expanded our knowledge of screen policy and screen industries and led to new fields of inquiry. These outcomes are important attributes and products of the structured workshop approach. 
Writing in 2020, one has to recognize that COVID-19 and the global climate emergency pose obvious challenges to the physical workshop setting. Hopefully there will soon be a time where one can conduct these kinds of on-site meetings again. If not, there are good reasons for exploring whether it might be worthwhile experimenting with structured online industry workshops in the years to come.

Furthermore, as research councils are becoming increasingly concerned with policy, societal, and industry impact as well as public engagement and as, especially, the humanities are increasingly required to justify their work and existence, as noted by, for example, Philip Schlesinger ${ }^{61}$ and Kelly and Champion, ${ }^{62}$ structured industry workshops can offer a methodology for achieving knowledge exchange and potential for impact. However, organizing and curating such workshops take substantial time and effort. The future of working more generally with this methodology is thus dependent on being able to obtain support for research designs that demand both time and funding on the part of the researchers.

${ }^{1}$ We would like to thank the participants in the workshops as well as the Royal Society of Edinburgh that funded this project with a workshop grant (172518).

${ }^{2}$ Eva Novrup Redvall is Associate Professor and Head of Section for Film and Creative Media Industries at the University of Copenhagen. Her research focuses on film and television screenwriting and production. From 2019 to 2024 she is PI of the research project "Reaching Young Audiences: Serial Fiction and Cross-media Storyworlds for Children and Young Audiences" (supported by Independent Research Fund Denmark). Among her latest books are the co-edited collections European Film and Television Co-production (2018) and Danish Television Drama: Global Lessons from a Small Nation (2020). She is also a board member of The Danish Film Institute and film critic for Information.

${ }^{3}$ Inge Ejbye Sørensen is Lecturer in Media Policy at Centre for Cultural Policy Research, University of Glasgow. Her research interests are the practices, policies, and political economy of national and international screen industries with particular focus on Public Service Media, VOD, and streaming services; screen agencies, institutions, and funding models; and interactive, mixed reality, and VR documentary and fact-based screen media. She is on the Steering group of Glasgow Film Festival's Industry Focus and advices the Scottish Parliament, national screen agencies, regulators, and trade unions. Inge is an award-winning Producer of documentary and fiction for BBC, Channel 4, Five, and STV.

${ }^{4}$ Hanne Bruun, "Eksklusive informanter: Om interviewet som redskab i produktionsanalysen [Exclusive Informants. About the Interview as a Method in Production Analysis]," Nordicom Information 36 (1, 2014): 29-43; and Hanne Bruun, "The Qualitative Interview in Media Production Studies," in Advancing Media Production Research: Shifting Sites, Methods, and Politics, ed. Chris Paterson, David Lee, Anamik Saha, and Anna Zoellner (Basingstoke: Palgrave Macmillan, 2016), 131-46.

${ }^{5}$ Please see David M. Ryfe, "The Importance of Time in Media Production Research," in Advancing Media Production Research: Shifting Sites, Methods, and Politics, ed. Chris Paterson, David Lee, Saha Amika, and Anna Zoellner (Basingstoke: 
Palgrave Macmillan, 2016), 38-50; Marc Brennan, "Happy to Help? Gaining Access to Interview Media Practitioners," Australian Journal of Communication 35 (1, 2008): 15-26; and Kirsten Frandsen and Hanne Bruun, "Tid og timing: Et metodisk perspektiv på produktionsanalyse [Time and Timing. A Methodological Perspective on Production Analysis]," Mediekultur 33 (62, 2017): 119-33, https://doi. org/10.7146/mediekultur.v33i62.25217.

${ }^{6}$ Bruun, "The Qualitative Interview in Media Production Studies," 131-46.

${ }^{7}$ John T. Caldwell, Production Culture: Industrial Reflexivity and Critical Practice in Film and Television (Durham, NC: Duke University Press, 2008), 3.

${ }^{8}$ Commissioning Creativity and Funding Film was funded by a workshop grant from Royal Society of Edinburgh, grant number 172518.

${ }^{9}$ Matthew Freeman, Industrial Approaches to Media: A Methodological Gateway to Industry Studies (London: Palgrave Macmillan, 2016), 56-57.

${ }^{10}$ Des Freedman, The Politics of Media Policy (Cambridge: Polity Press, 2008), vii.

${ }^{11}$ To mention but a few: Ina Bertrand and Peter Hughes, Media Research Methods: Audiences, Institutions, Texts, 2nd ed. (London: Palgrave Macmillan, 2018); Klaus Bruhn Jensen, ed., A Handbook of Media and Communication Research, 2nd ed. (London: Routledge, 2012); John Creswell, Research Design: Qualitative, Quantitative, and Mixed Methods Approaches, 4th ed. (Thousand Oaks, CA: SAGE, 2014); David Deacon, Michael Pickering, Peter Golding, and Graham Murdock, Researching Communications: A Practical Guide to Methods in Media and Cultural Analysis, 2nd ed. (London: Hodder Arnold, 2007); Uwe Flick, Introducing Research Methodology: A Beginner's Guide to Doing a Research Project, 2nd ed. (Los Angeles, CA: SAGE, 2015); Anders Hansen and David Machin, Media and Communication Research Methods (Basingstoke: Palgrave Macmillan, 2013); Keith Punch, Introduction to Social Research: Quantitative and Qualitative Approaches, 3rd ed. (London: SAGE, 2013); David Silverman, Interpreting Qualitative Data: Methods for Analyzing Talk, Text, and Interaction, 3rd ed. (London: SAGE, 2006); Jane Stokes, How to Do Media and Cultural Studies, 2nd ed. (London: SAGE, 2013).

${ }^{12}$ Alan Bryman, Social Research Methods (Oxford: Oxford University Press, 2016), 16.

${ }^{13}$ As discussed in, for example, Brennan, "Happy to Help? Gaining Access to Interview Media Practitioners"; Raymond Boyle, The Talent Industry: Television, Cultural Intermediaries and New Digital Pathway (London: Palgrave Macmillan, 2018); and Jennifer Holt and Alisa Perren, eds, Media Industries: History, Theory, and Method. (Oxford: Wiley Blackwell, 2009).

14 Bruun, "Eksklusive informanter: Om interviewet som redskab i produktionsanalysen"; and Bruun, "The Qualitative Interview in Media Production Studies."

${ }^{15}$ Frandsen and Bruun, "Tid og timing: Et metodisk perspektiv på produktionsanalyse"; and Ryfe, "The Importance of Time in Media Production Research."

${ }^{16}$ Caldwell, Production Culture, 3.

${ }^{17}$ Freeman, Industrial Approaches to Media, 57.

${ }^{18}$ Vicki Mayer, Below the Line: Producers and Production Studies in the New Television Economy (Durham, NC: Duke University Press, 2011); Vicki Mayer, "Studying Up and $\mathrm{F}^{* * *}$ Ing Up: Ethnographic Interviewing in Production Studies," Cinema Journal 247 (2, 2008): 141-48. 
${ }^{19}$ Sherry B. Ortner, "Studying Sideways: Ethnographic Access in Hollywood," in Production Studies: Cultural Studies of Media Industries, ed. Vicki Mayer, Miranda J. Banks, and John T. Caldwell (NY: Routledge, 2009), 175-89; and Traube as cited in Ortner, "Studying Sideways."

${ }^{20}$ John T. Caldwell, "'Both Sides of the Fence': Blurred Distinctions in Scholarship and Production (a Portfolio of Interviews)," in Production Studies: Cultural Studies of Media Industries, ed. Vicki Mayer, Miranda J. Banks, and John T. Caldwell (NY: Routledge, 2009), 214-16.

${ }^{21}$ For example, Steinar Kvale and Svend Brinkmann, Interview: Det kvalitative forskningsinterview som håndværk [The Qualitative Research Interview as Practice] (Copenhagen: Hans Reitzels Forlag, 2014).

22 For example, Bruun, "The Qualitative Interview in Media Production Studies."

${ }^{23}$ For example, Gillian Doyle, Philip Schlesinger, Raymond Boyle, and Lisa Kelly, The Rise and Fall of the UK Film Council (Edinburgh: Edinburgh University Press, 2015); and Jesper Strandgaard Pedersen, Per Darmer, and Chris Mathieu, "Bureaucracies and Judgemental Autonomy-Film Consultants in a Public Film Institute," The Nordic Journal of Cultural Policy 16 (1, 2013): 68-89.

${ }^{24}$ Christian Herzog and Christopher Ali, "Elite Interviewing in Media and Communications Policy Research," International Journal of Media \& Cultural Politics 11 (1, 2015): 37-54.

${ }^{25}$ Barbara Czarniawska, "Fieldwork Techniques for Our Times: Shadowing," in Qualitative Methodologies in Organization Studies: Volume II: Methods and Possibilities, ed. Malgorzata Ciesielska and Dariusz Jemielniak (Cham: Springer International Publishing, 2018), 53-74.

${ }^{26}$ Georgina Born, Uncertain Vision: Birt, Dyke and the Reinvention of the BBC (London: Vintage, 2005) and Philip Schlesinger. Putting "Reality" Together: BBC News (London: Constable, 1987).

${ }^{27}$ John T. Caldwell, "Production Cultures: How to Study Deep Texts, Reflexive Rituals, and Managed Self-Discourses," in Media Industries: History, Theory, and Method, ed. Jennifer Holt and Alisa Perren (Malden, MA: Blackwell, 2009), 199-212.

${ }^{28}$ Timothy Havens, Global Television Marketplace (London: British Film Institute, 2006).

${ }^{29}$ For example, Freeman, Industrial Approaches to Media; and Chris Paterson, David Lee, Anamik Saha, and Anna Zoellner, Advancing Media Production Research (Basingstoke: Palgrave Macmillan, 2016).

${ }^{30}$ Caldwell, Production Culture, 36.

${ }^{31}$ See, for example, Eva N. Redvall, Writing and Producing Television Drama in Denmark: From The Kingdom to The Killing (Basingstoke: Palgrave Macmillan, 2013); and Eva N. Redvall, "Dialogues between Audience Research and Production: The History of Testing Television Drama for the Danish Broadcasting Corporation (DR)," Critical Studies in Television 4 (12, 2017): 346-61; or Eva N. Redvall, "International Co-production of Nordic Television Drama: The Case of Ride Upon the Storm," in European Film and Television Co-production: Policy and Practice, ed. Julia HammettJamart, Petar Mitric, and Eva N. Redvall (Basingstoke: Palgrave Macmillan, 2018), 137-52; Inge E. Sørensen, "Channels as Content Curators: Multiplatform Strategies 
for Documentary Film and Factual Content in British Public Service Broadcasting," European Journal of Communication 29 (1, 2014): 34-49; and Inge E. Sørensen, "Content in Context: The Impact of Mobile Media and Technology on the British TV Industry," Convergence 24 (2018): 507-22; or Inge E. Sørensen, "The Revival of Live TV: Lives Across Platforms and Devices," Media, Culture E Society 38 (3, 2016): 381-99.

${ }^{32}$ Bertrand and Hughes, Media Research Methods, 171.

${ }^{33}$ Lisa W. Kelly and Katherine Champion, "Shaping Screen Talent: Conceptualising and Developing the Film and TV Workforce in Scotland," Cultural Trends 24 (2, 2015): 165-75.

${ }^{34}$ www.euroarabchildrensmedia.org. See also Naomi Sakr and Jeanette Steemers, "Co-Producing Content for Pan-Arab Children's TV: State, Business and the Workplace," in Production Studies, The Sequel!, ed. Miranda Banks, Bridget Conor, and Vicki Mayer (London: Routledge, 2016), 238-50; and Naomi Sakr and Jeanette Steemers, Screen Media for Arab and European Children: Policy and Production Encounters in the Multiplatform Era (Basingstoke: Palgrave Pivot, 2019).

${ }^{35}$ www.transforminghollywood.tft.ucla.edu.

${ }^{36}$ www.carseywolf.ucsb.edu/research/industry/media-industries-project/

${ }^{37}$ Further details can be found on the project's website: https://www.gla.ac.uk/ schools/cca/research/ccpr/researchinccpr/commissioningcreativityandfund ingfilmsworkshops2016-17/

${ }^{38}$ The workshop participants were Claus Ladegaard (Head of Film Funding, Danish Film Institute), Marie Schmidt Olsen (Funder, New Danish Screen), Vinca Wiedemann (Principal, the National Film School of Denmark), Elin Erichsen (Head of Production, Norwegian Film Institute), Dag Asbjørnsen (Head of International, Norwegian Film Institute), Natalie Usher (Director of Screen, Creative Scotland), Scott Donaldson (Head of Film Education, Creative Scotland), Frank Peijnenburg (Director, Screen Netherlands), Yaba Holst (Funder, Swedish Film Institute), and Agnieszka Moody (Director, Creative Europe Desk, UK). Academic participants were the authors of this article: Professors Gillian Doyle, Philip Schlesinger, Martin Kretschmer, and Raymond Boyle from the University of Glasgow and PhD candidate Petar Mitric of the University of Copenhagen.

${ }^{39}$ For example, Freeman, Industrial Approaches to Media, 28.

${ }^{40}$ See, for example, Deacon et al., Researching Communications, 54-55.

${ }^{41}$ Jennifer Holt, "Two-Way Mirrors: Looking at the Future of Academic-Industry Engagement," Cinema Journal 52 (3, 2013): 183-88.

${ }^{42}$ In addition to Caldwell's work already mentioned above, see in particular Caldwell, "Production Cultures."

${ }^{43}$ Alison Preston, Inside the Commissioners (Glasgow: The Research Center, Scottish Enterprise, Stirling Media Institute, Channel 4, 2003).

${ }^{44}$ Caldwell, Production Culture, 5.

${ }^{45}$ For a discussion of the importance of trust when working with industry practitioners, see, for example, Anna Potter, "Managing Productive Academia/Industry Relations: The Interview as Research Method," Media Practice and Education 19 (3, 2018): 159-72. 
${ }^{46}$ Patrick Vonderau, "Access and Mistrust in Media Industries Research," in Making Media: Production, Practices, and Professions, ed. Mark Deuze and Mirjam Prenger (Amsterdam: Amsterdam University Press, 2019), 61-72.

${ }^{47}$ Flick, Introducing Research Methodology, 147.

${ }^{48}$ Flick, Introducing Research Methodology, 147.

${ }^{49}$ Timothy Havens, Black Television Travels: African American Media around the Globe (NY: New York University Press, 2013) and Havens, Global Television Marketplace.

${ }^{50}$ Jeanette Steemers, "Policy and Production Encounters around Children's 'Television' and Diversity: Facilitating Arab-European Dialogue," Keynote Lecture at The Youthification of Television conference (University of Groningen, 2019).

${ }^{51}$ Mikhail Bakhtin, "The Dialogic Imagination: Four Essays," in Modern Criticism and Theory: A Reader, ed. David Lodge (London: Longman, 1981), 125-56.

${ }^{52}$ Amanda D. Lotz and Horace Newcomb, "The Production of Entertainment Media," in A Handbook of Media and Communication Research, ed. Klaus Bruhn Jensen (London: Routledge, 2012), 71-86.

${ }^{53}$ Eva N. Redvall and Inge E. Sørensen, "Hard Facts, Soft Measures: Gender, Quality and Inequality Debates in Danish Film and Television in the 2010s," Journal of Scandinavian Cinema 8 (3, 2018): 235-51.

${ }^{54}$ See Inge E. Sørensen and Eva N. Redvall, "Does 'Automatic Funding Suck'? The Value of Automatic Funding in Smaller Northern European Screen Industries," International Journal of Cultural Policy (2020), https://www.tandfonline.com/ doi/abs /10.1080/10286632.2020.1724107?journalCode=gcul20

${ }^{55}$ Holt, "Two-Way Mirrors."

${ }^{56}$ John Ellis, as cited in Freeman, Industrial Approaches to Media, 214.

${ }^{57}$ Potter, "Managing Productive Academia/Industry Relations."

${ }^{58}$ Janice Radway, "Ethnography among Elites: Comparing Discourses of Power," Journal of Communication Inquiry 13 (3, 1989): 3-11.

${ }^{59}$ See, for example, Jennifer Holt and Alisa Perren, "Media Industries: A Decade in Review," in Making Media: Production, Practices, Professions, ed. Mark Deuze and Mirjam Prenger (Amsterdam: Amsterdam University Press, 2019), 31-44; Ramon Lobato, "Rethinking International TV Flows Research in the Age of Netflix," Television E New Media 19 (3, 2018): 241-56.

${ }^{60}$ Paterson, Lee, Saha and Zoellner, Advancing Media Production Research, 8.

${ }^{61}$ Philip Schlesinger, "The Vagaries of Production Research," in Advancing Media Production Research, ed. Chris Paterson, David Lee, Anamik Saha, and Anna Zoellner (Basingstoke: Palgrave Macmillan, 2016), 20-38.

62 Kelly and Champion, "Shaping Screen Talent."

\section{Bibliography}

Bakhtin, Mikhail. "The Dialogic Imagination: Four Essays." In Modern Criticism and Theory: A Reader, edited by David Lodge and Nigel Wood, 125-56. London: Longman, 1981.

Bertrand, Ina, and Peter Hughes. Media Research Methods: Audiences, Institutions, Texts. 2nd ed. London: Palgrave Macmillan, 2018. 
Born, Georgina. Uncertain Vision: Birt, Dyke and the Reinvention of the BBC. London: Vintage, 2005.

Boyle, Raymond. The Talent Industry. Television, Cultural Intermediaries and New Digital Pathway. London: Palgrave Macmillan, 2018.

Brennan, Marc. "Happy to Help? Gaining Access to Interview Media Practitioners." Australian Journal of Communication 35, no. 1 (2008): 15-26.

Bruun, Hanne. "Eksklusive informanter: Om interviewet som redskab i produktionsanalysen [Exclusive Informants. About the Interview as a Method in Production Analysis]." Nordicom Information 36, no. 1 (2014): 29-43.

Bruun, Hanne. "The Qualitative Interview in Media Production Studies." In Advancing Media Production Research, edited by Chris Paterson, David Lee, Anamik Saha, and Anna Zoellner, 131-46. Basingstoke: Palgrave Macmillan, 2016.

Caldwell, John T. "Both Sides of the Fence': Blurred Distinctions in Scholarship and Production (a Portfolio of Interviews)." In Production Studies: Cultural Studies of Media Industries, edited by Vicki Mayer, Miranda J. Banks, and John T. Caldwell, 214-30. New York: Routledge, 2009.

Caldwell, John T. Production Culture: Industrial Reflexivity and Critical Practice in Film and Television. Durham, NC: Duke University Press, 2008.

Caldwell, John T. "Production Cultures: How to Study Deep Texts, Reflexive Rituals, and Managed Self-Discourses." In Media Industries: History, Theory, and Method, edited by Jennifer Holt and Alisa Perren, 199-212. Malden, MA: Blackwell, 2009.

Creswell, John W. Research Design: Qualitative, Quantitative, and Mixed Methods Approaches. 4th ed. Thousand Oaks, CA: SAGE, 2014.

Czarniawska, Barbara. "Fieldwork Techniques for Our Times: Shadowing." In Qualitative Methodologies in Organization Studies: Volume II: Methods and Possibilities, edited by Malgorzata Ciesielska and Dariusz Jemielniak, 53-74. Cham: Springer International Publishing, 2018.

Czarniawska, Barbara. Shadowing: And Other Techniques for Doing Fieldwork in Modern Societies. Copenhagen: CBS Press, 2007.

Deacon, David, Michael Pickering, Peter Golding, and Graham Murdock. Researching Communications: A Practical Guide to Methods in Media and Cultural Analysis. 2nd ed. London: Hodder Arnold, 2007.

Deuze, Mark, and Mirjam Prenger, eds. Making Media: Production, Practices, Professions. Amsterdam: Amsterdam University Press, 2019.

Doyle, Gillian, Philip Schlesinger, Raymond Boyle, and Lisa Kelly. The Rise and Fall of the UK Film Council. Edinburgh: Edinburgh University Press, 2015.

Flick, Uwe. Introducing Research Methodology: A Beginner's Guide to Doing a Research Project. 2nd ed. Los Angeles, CA: SAGE, 2015. 
Frandsen, Kirsten, and Hanne Bruun. "Tid og timing: Et metodisk perspektiv på produktionsanalyse [Time and Timing: A Methodological Perspective on Production Analysis]." Mediekultur 33, no. 62 (2017): 119-33.

Freedman, Des. The Politics of Media Policy. Cambridge: Polity Press, 2008.

Freeman, Matthew. Industrial Approaches to Media: A Methodological Gateway to Industry Studies. London: Palgrave Macmillan, 2016.

Hansen, Anders, and David Machin. Media and Communication Research Methods. Basingstoke: Palgrave Macmillan, 2013.

Havens, Timothy. Black Television Travels: African American Media Around the Globe. New York: New York University Press, 2013.

Havens, Timothy. Global Television Marketplace. London: British Film Institute, 2006.

Herzog, Christian, and Christopher Ali. "Elite Interviewing in Media and Communications Policy Research." International Journal of Media E Cultural Politics 11, no. 1 (2015): 37-54.

Holt, Jennifer. "Two-Way Mirrors: Looking at the Future of Academic-Industry Engagement." Cinema Journal 52, no. 3 (2013): 183-88.

Holt, Jennifer, and Alisa Perren. Media Industries: History, Theory, and Method. Oxford: Wiley Blackwell, 2009.

Jensen, Klaus Bruhn. A Handbook of Media and Communication Research, edited by Klaus Bruhn Jensen. 2nd ed. London: Routledge, 2012.

Jensen, Klaus Bruhn. "New Media, Old Methods: The Online/Offline Divide." In The Handbook of Internet Studies, edited by Mia Consalvo and Charles Ess, 43-58. Malden, MA: Wiley Blackwell, 2011.

Kelly, Lisa W., and Katherine Champion. "Shaping Screen Talent: Conceptualising and Developing the Film and TV Workforce in Scotland." Cultural Trends 24, no. 2 (2015): 165-75.

Kvale, Steinar, and Svend Brinkmann. Interview-Det kvalitative forskningsinterview som håndværk [The Qualitative Research Interview as Practice]. Copenhagen: Hans Reitzels Forlag, 2014.

Lobato, Ramon. "Rethinking International TV Flows Research in the Age of Netflix." Television E New Media 19, no. 3 (2018): 241-56.

Lotz, Amanda D., and Horace Newcomb. "The Production of Entertainment Media." In A Handbook of Media and Communication research, edited by Klaus Bruhn Jensen, 71-86. London: Routledge, 2012.

Mayer, Vicki. Below the Line: Producers and Production Studies in the New Television Economy. Durham, NC: Duke University Press, 2011.

Mayer, Vicki. "Studying Up and $\mathrm{F}^{* * * i n g ~ U p: ~ E t h n o g r a p h i c ~ I n t e r v i e w i n g ~ i n ~ P r o d u c t i o n ~}$ Studies." Cinema Journal 247, no. 2 (2008): 141-48. 
Ortner, Sherry B. "Studying Sideways: Ethnographic access in Hollywood." In Production Studies: Cultural Studies of Media Industries, edited by Vicki Mayer, Miranda J. Banks, and John T. Caldwell, 175-89. New York: Routledge, 2009.

Paterson, Chris, David Lee, Anamik Saha, and Anna Zoellner. Advancing Media Production Research. Basingstoke: Palgrave Macmillan, 2016.

Pedersen, Jesper Strandgaard, Per Darmer, and Chris Mathieu. "Bureaucracies and Judgemental Autonomy: Film Consultants in a Public Film Institute." The Nordic Journal of Cultural Policy 16, no. 1 (2013): 68-89.

Potter, Anna. "Managing Productive Academia/Industry Relations: The Interview as Research Method." Media Practice and Education 19, no. 2 (2018): 159-72.

Preston, Alison. Inside the Commissioners. Glasgow: The Research Centre, Scottish Enterprise, Stirling Media Institute, Channel 4, 2003.

Punch, Keith F. Introduction to Social Research: Quantitative and Qualitative Approaches. 3rd ed. London: SAGE, 2013.

Radway, Janice. "Ethnography among Elites: Comparing Discourses of Power." Journal of Communication Inquiry 13, no. 3 (1989): 3-11.

Redvall, Eva N. Writing and Producing Television Drama in Denmark: From The Kingdom to the Killing. Basingstoke: Palgrave Macmillan, 2013.

Redvall, Eva N. "Dialogues between Audience Research and Production: The History of Testing Television Drama for the Danish Broadcasting Corporation (DR)." Critical Studies in Television 4, no. 12 (2017): 346-61.

Redvall, Eva N. "International Co-production of Nordic Television Drama: The Case of Ride Upon the Storm." In European Film and Television Co-production: Policy and Practice, edited by Julia Hammett-Jamart, Petar Mitric, and Eva N. Redvall, 137-52. Basingstoke: Palgrave Macmillan, 2018.

Redvall, Eva N., and Inge E. Sørensen. "Hard Facts, Soft Measures: Gender, Quality and Inequality Debates in Danish Film and Television in the 2010s." Journal of Scandinavian Cinema 8, no. 3 (2018): 235-51.

Ryfe, David M. "The Importance of Time in Media Production Research." In Advancing Media Production Research: Shifting Sites, Methods, and Politics, edited by Chris Paterson, David Lee, Saha Amika, and Anna Zoellner, 38-50. Basingstoke: Palgrave Macmillan, 2016.

Sakr, Naomi, and Jeanette Steemers. "Co-Producing Content for Pan-Arab Children's TV: State, Business and the Workplace." In Production Studies, The Sequel!, edited by Miranda Banks, Bridget Conor, and Vicki Mayer, 238-50. London: Routledge, 2016.

Sakr, Naomi, and Jeanette Steemers. Screen Media for Arab and European Children: Policy and Production Encounters in the Multiplatform Era. Basingstoke: Palgrave Pivot, 2019.

Schlesinger, Philip. Putting "Reality" Together: BBC News. London: Constable, 1987. 
Schlesinger, Philip. "The Vagaries of Production Research." In Advancing Media Production Research: Shifting Sites, Methods and Politics, edited by Chris Paterson, David Lee, Anamik Saha, and Anna Zoellner, 20-38. Basingstoke: Palgrave Macmillan, 2016.

Silverman, David. Interpreting Qualitative Data: Methods for Analyzing Talk, Text, and Interaction. 3rd ed. London: SAGE, 2006.

Steemers, Jeanette. "Policy and Production Encounters around Children's 'Television' and Diversity: Facilitating Arab-European Dialogue." Keynote Lecture at The Youthification of Television conference. University of Groningen, 2019.

Stokes, Jane. How to Do Media and Cultural Studies. 2nd ed. London: SAGE, 2013.

Sørensen, Inge E. "Channels as Content Curators: Multiplatform Strategies for Documentary Film and Factual Content in British Public Service Broadcasting." European Journal of Communication 29, no. 1 (2014): 34-49.

Sørensen, Inge E. "Content in Context: The Impact of Mobile Media and Technology on the British TV Industry." Convergence 24 (2018): 507-22.

Sørensen, Inge E. "The Revival of Live TV: Lives Across Platforms and Devices." Media, Culture E Society 38, no. 3 (2016): 381-99.

Sørensen, Inge E., and Eva N. Redvall. "Does 'Automatic Funding Suck'? The Value of Automatic Funding in Smaller Northern European Screen Industries." International Journal of Cultural Policy (2020). https://www.tandfonline.com/doi/abs/10.1080/10286632.2 020.1724107?journalCode $=$ gcul20

Vonderau, Patrick. "Access and Mistrust in Media Industries Research." In Making Media: Production, Practices, and Professions, edited by Mark Deuze and Mirjam Prenger, 61-72. Amsterdam: Amsterdam University Press, 2019. 